\title{
The Virus Diseases of Crotalaria, Glycine and Medicago Species
}

\author{
by
}

\author{
Patricia J. Klesser
}

\section{Division of Plant Pathology}

This report concerns the naturally occurring virus diseases of the following plants:-

Crotalaria juncea (sunnhemp), C. spectabilis, Glycine max (soybean), G. javanica and Medicago sativa (lucerne or alfalfa).

Throughout South Africa, these genera are used either for fodder, as cover crops, or, to a lesser extent, for oil extraction.

Further details of some of the diseases found on these plants, will be found in the reports on bean and broad bean virus diseases, as the viruses were apparently related to those groups.

\section{METHODS AND MATERIALS}

The viruses were isolated from plants collected mainly in the Transvaal, but also from the Stellenbosch district and from near Salisbury, Southern Rhodesia.

The standard test plants were: Phaseolus vulgaris var. Canadian Wonder, Vicia faba var. Aquedulce, Pisum sativum var. Greenfeast and Vigna unguiculata var. Dr. Saunder's Upright.

Carborundum powder was used for the mechanical sap inoculations, and Aphis craccivora was used in the insect transmission tests.

There are three separate sections, dealing with the viruses of (A) Crotalaria spp. (B) Glycine max and (C) Medicago sativa and Glycine javanica.

Each section has its own bibliography and plates.

\section{CROTALARIA VIRUS DISEASES}

Crotalaria juncea, sunnhemp. is cultivated extensively in South Africa as a green manure crop. Crotalaria spectabilis is also used for this purpose but on a smaller scale.

Both species are subject to natural infection by several viroses in the field, and are also susceptible to many others when inoculated artificially.

With two exceptions, these virus diseases have been described in previous papers, as they were obviously related to other viruses viz. the bean local chlorosis, the bean chlorotic ringspot, the bean necrosis and the bean necrotic speckle viruses. Also, a strain of the broad bean mosaic virus was found on naturally infected $C$. spectabilis.

The two exceptions, which will be described in detail in this paper, are the alsike clover mosaic virus and the white clover mosaic virus complex. Both are well-known elsewhere, but are recorded for the first time in South Africa.

The symptoms caused on most host plants, by what is considered to be the white clover mosaic virus, are very similar to those described by Zaumeyer and Wade (19). No attempt has been made to split the components [see Johnson (13)], but the virosis as found in the field is described as a whole. 
The symptoms caused by the several viruses on $C$. juncea are very similar-the differences are found in the degree of malformation, mottling or necrosis rather than in the type of symptom. They are only differentiated by the effect of the virus on other plants.

On $C$. spectabilis the symptom picture does vary-some viruses cause vivid yellow streaks, while others result in mottling with necrosis.

Nevertheless, they are not characteristic enough for certain identification, and alternate hosts must be used.

\section{REVIEW OF LITERATURE}

The first report of probable virus infections of Crotalaria species was that of Schwartz, 1927, who described a witch's broom and crinkle disease of $C$. juncea and C. anagyroides in Java (17).

In 1931. Illingworth (11) noted a mosaic of Crotalarias in pineapple fields in Hawaii, and Cook $(5,6)$ worked on a mosaic disease of $C$. striata in Puerto Rico. Other mosaic diseases of Crotalaria spp. were found in Japan by Fukushi (8), and in Trinidad by Dale (7).

Raychaudhuri (15) noted a mosaic disease which is confined to sunnhemp only (C. juncea) and Capoor (4) described the Southern sunnhemp mosaic virus which withstands very high temperatures and ageing.

Gates (9) reported mosaic and "little leaf" diseases of $C$. spectabilis, Jenson (12) worked on the aphid transmission of a mosaic of $C$. incana and Raychaudhuri and Pathanian (16) found a mosaic of $C$. striata.

Viruses causing a witch's broom symptom on Crotalaria spp. were recorded by Johnson and Lefebvre (14) who were able to transmit the virus to broad bean; and Hadiwidjaja (10) who transmitted the virus by grafting and by Cuscuta.

Bose and Misra (3) reported a graft-transmissible virus which caused structural abnormalities of sunnhemp flowers. This was later proved to be due to two virusesone sap-transmissible, and the other. probably tobacco leaf-curl transmitted by Bemisia tabaci (1).

According to Zaumeyer (18), mosaic symptoms can be induced on Crotalaria spp. by artificial inoculation with several legume viruses viz. alsike clover mosaic viruses 1 and 2 and pea mosaic viruses 4 and 5 .

\section{Alsike ClOVER MOSAIC VIRUS I Zaumeyer and Wade.}

Natural source of virus: Crotalaria juncea.

The young leaves showed a chlorotic speck mottle and they had wavy margins. The middle leaves had constrictions across the laminae, and irregular-shaped dark green islands on a light green background. The lower leaves were normal in shape but had dark green veinbands or midrib. Fig. IA.

Physical properties: Thermal inactivation point $62-64^{\circ} \mathrm{C}$. Longevity in vitro 1-2 days. Dilution end point 1:3000-1:5000.

Transmission: Mechanical sap inoculation. Aphis craccivora.

Host range: Crotalaria juncea L., C. spectabilis Roth., Dolichos lablab L., Glycine javanica L., G. max (L.) Merr., Lathyrus odoratus L., Lupinus albus L., L. luteus L., L. mutabilis Sweet., Medicago lupulina L., Melilotus officinalis Willd., Phaseolus acutifolius Gray var. latifolius Freem., P. lunatus L., P. mungo L., P. vulgaris L., Pisum sativum L., Trifolium hybridum L., T. incarnatum L., T. pratense L., Vicia faba L., Vigna sesquipedalis (L.) Wight., V. unguiculata (L.) Walp., Voandzeia subterranea Thouars. 


\section{REACTION OF SUSCEPTIBLE SPECIES}

\section{Crotalaria juncea.}

Local. Necrotic lesions may develop.

Systemic. In nine days chlorotic spots develop on the young leaves. Later leaves have a mottle or mosaic with dark green blisters or veinbands. These leaves are puckered, malformed and elongated. There may also be necrotic specks. Fig. 1 B. The plant is stunted and rosetted.

C. spectabilis.

Local. Chlorotic spots may develop.

Systemic. There are chlorotic spots on the young leaves in 19 days. Later leaves are chlorotic with dark green veinbands and there is a necrotic sheen. These leaves are malformed and puckered.

\section{Dolichos lablab.}

A symptomless carrier.

Glycine javanica.

Local. There are chlorotic spots in seven days.

Systemic. There may be a chlorotic spotting or mottle.

G. max.

Local. Chlorotic spots develop in seven days.

Systemic. There may be chlorotic areas, but usually the virus is latent.

Lathyrus odoratus.

Local. No reaction.

Systemic. The leaves are rolled and mottled.

Lupinus albus var. Sweet.

Local. The leaves drop after a severe necrosis in three days.

Systemic. In 16 days the young leaves develop a vein clearing and spotting and they remain folded, and have wavy margins. Later leaves are mottled and malformed and may have necrotic specks. The plant is rosetted and many leaves drop.

L. albus var. Bitter.

Local. No reaction.

Systemic. The young leaves remain folded and have curled tips. Later leaves are mottled or generally chlorotic and the plant is rosetted.

\section{L. luteus.}

Local. No reaction.

Systemic. The young leaves remain folded and have wavy margins. Chlorotic spots develop in 20 days. Later leaves are small, malformed (stringlike) and generally chlorotic. There may be necrosis and many leaves drop. The plant is rosetted.

\section{L. mutabilis.}

Local. No reaction.

Systemic. The leaves are malformed and stringlike, and very chlorotic. The plant is rosetted.

\section{Medicago lupulina.}

Local. No reaction. 
Systemic. After a vein clearing there are vivid chlorotic streaks and areas, and the leaves are crinkled. Fig. 1C.

Melilotus officinalis.

Local. No reaction.

Systemic. The young leaves develop chlorotic spots and streaks. Later leaves are mottled, small and malformed.

\section{Phaseolus acutifolius.}

Local. In six days there are chlorotic spots and necrotic veins.

Systemic. The young leaves develop a vein clearing and then necrosis in the veins. Later leaves are mottled.

\section{$P$. lunatus.}

Local. Chlorotic ringspots develop in six days.

Systemic. There is a chlorosis of the veins which soon becomes necrotic.

\section{P. mungo.}

Local. There are chlorotic spots in eight days.

Systemic. There is a chlorotic spotting on most leaves.

$P$. vulgaris var. Canadian Wonder.

Local. No reaction.

Systemic. A chlorotic network develops on the young leaves, and later ones have a chlorotic spotting and then a mottle. There are dark green areas and veinbands and the leaves are puckered.

$$
\text { var. Haricot. }
$$

Local. No reaction.

Systemic. After a chlorotic network and spotting, the leaves develop a mottle. The leaf surface is puckered and many leaves drop. There may be a slight malformation.

\section{Pisum sativum.}

Local. No reaction.

Systemic. The young leaves develop a chlorotic network in 15 days. Later leaves have chlorotic spots or a mottle, and are malformed. The old leaves have a white etching. Fig. 1D. The tendrils are abnormally curled, and the plant is stunted.

Trifolium hybridum.

Local. No reaction. streaking.

Systemic. There is a vein clearing and chlorotic spotting followed by a chlorotic

\section{$T$. incarnatum.}

Local. There may be dark green rings on the chlorotic leaves.

Systemic. The young leaves show a vein clearing after six days, then chlorotic spotting or vein flecking. Later leaves have a mosaic and are crinkled and rosetted.

\section{$T$. pratense.}

Local. No reaction. carrier.

Systemic. There may be chlorotic streaks or the plant may be a symptomless

\section{Vicia faba.}

Local. No reaction.

Systemic. Only a diffuse chlorotic mottle develops. 
Vigna sesquipedalis.

Local. There are chlorotic spots in seven days.

Systemic. In 15 days the young leaves develop a vein clearing and chlorotic spotting. Later leaves are mottled.

\section{V. unguiculata.}

Local. Chlorotic spots may develop.

Systemic. There may be a vein clearing followed by a chlorotic mottle, or the leaves may be symptomless.

\section{Voandzeia subterranea.}

Local. There are chlorotic areas in seven days.

Systemic. The symptoms are masked.

\section{IDENTIFICATION.}

This virus is very similar to the alsike clover mosaic virus 1 Zaumeyer and Wade (19). The only difference is that on the broad bean, Zaumeyer's virus induces a severe mottle and malformation, whereas this virus causes only a diffuse mottling. This difference may be due to temperature or varietal factors.

Nevertheless, it is considered the same as, or closely related to the alsike clover mosaic virus 1 .

\section{WHITE CLOVER MOSAIC VIRUS Zaumeyer and Wade.}

Natural source of virus: Crotalaria spectabilis.

The younger leaves showed a chlorotic mottle, and the older ones, a dark green vein banding. There were necrotic stem streaks. Fig. 2C.

Physical properties: Thermal inactivation point $56-58{ }^{\circ} \mathrm{C}$. Longevity in vitro 1-2 days. Dilution end point $1: 1000-1: 2000$.

Transmission: Mechanical sap inoculation.

Host range: Arachis hypogaea L., Crotalaria juncea L., C. spectabilis Roth., Dolichos lablab L., Glycine javanica L., G. max (L.) Merr.. Lathyrus odoratus L., Lupinus albus L., L. luteus L., L. mutabilis Sweet., Medicago lupulina L., M. sativa L., Melilotus officinalis Willd., Phaseolus acutifolius Gray var. latifolius Freem., P. lunatus L., P. mungo L., $P$. vulgaris L., Pisum sativum L., Trifolium hybridum L., T. incarnatum L.. T. pratense L., T. repens L., Vicia faba L., Vigna sesquipedalis (L.) Wight., V. unguiculata (L.) Walp., Voandzeia subterranea Thouars.

\section{REACTION OF SUSCEPTIBLE SPECIES}

Arachis hypogaea.

Local. No reaction.

Systemic. Chlorotic spots develop on the young leaves; on later formed ones, there is a chlorotic streak mottle.

Crotalaria juncea.

Local. Within a week there are chlorotic spots and necrotic veins. The leaves soon drop.

Systemic. In nine days the young leaves develop a vein clearing and chlorotic spotting. Later leaves are small and crinkled, and have a mosaic and a necrotic sheen. There are often necrotic stem streaks which cause the plant to curve tc one side. 
C. spectabilis.

Local. No reaction.

Systemic. The young leaves develop a chlorotic flecking and the next formed have a mottle. Later leaves develop a vein banding with a slight necrosis which causes a crinkling of the leaves.

Dolichos lablab.

Local. Chlorotic spots develop in 5-6 days.

Systemic. No reaction.

Glycine javanica.

A symptomless carrier.

Glycine max.

Local. Small necrotic specks with chlorotic haloes develop in 10 days.

Systemic. At the same time the young leaves develop a vein-clearing and chlorotic spotting. Later leaves have a mottle with necrosis developing in the chlorosis. This results in a puckering of the leaf surface.

Lathyrus odoratus.

Local. No reaction.

Systemic. After two weeks most leaves develop a chlorotic streak mottle and they are rolled.

Lupinus albus.

Local. In nine days necrotic specks and veins develop, leaving a chlorotic background. The leaflets soon drop.

Systemic. The young leaves show a veinclearing and spotting with necrotic specks. Later leaves are mottled and rolled, and the necrosis spreads until most leaves have dropped leaving the rosetted petioles. Any secondary shoots have small malformed leaves with dark green blisters.

L. luteus.

Local. In 10 days there are chlorotic spots.

Systemic. At the same time the young leaves develop a chlorotic network or vivid rings. Later leaves are mottled and malformed, and they remain folded. The older leaves have chlorotic spots with necrotic rings. The plant is severely stunted and rosetted.

\section{L. mutabilis.}

Local. No reaction.

Systemic. The leaves curl up, and are small and chlorotic. The plant is rosetted and stunted.

\section{Medicago lupulina.}

Local. No reaction.

Systemic. The leaves show chlorotic streaks and a dark green midrib. The plant is stunted.

M. sativa.

Local. No reaction.

Systemic. The young leaves develop chlorotic spots in three weeks. Subsequent ones show almost yellow spots or irregular areas.

Melilotus officinalis.

Local. There are dark green rings on chlorotic leaves. 
Systemic. The young leaves show diffuse chlorotic spots. Later ones develop an irregular chlorotic mottle.

\section{Phaseolus acutifolius.}

Local. There is no reaction but the leaves drop.

Systemic. In 8-10 days there is a veinclearing and curling of the young leaves. Later ones are small and malformed, and have dark green blisters.

\section{$P$. lunatus.}

Local. In 10 days there are necrotic specks with chlorotic haloes, and a veinal necrosis.

Systemic. The first and second trifoliates develop necrotic rings, and the young leaves have chlorotic specks with necrosis setting in.

\section{P. mungo.}

Local. In 10 days there are necrotic lesions.

Systemic. Some leaves have chlorotic specks which later become necrotic.

$P$. vulgaris var. Canadian Wonder.

Local. There are necrotic lesions or ringspots and a slight veinal necrosis.

Systemic. No reaction. var. Haricot.

Local. Within a week there may be small chlorotic spots with necrotic rings, or only a veinal necrosis.

Systemic. The young leaves develop a veinal necrosis which spreads to the petioles and stem, and the plant collapses.

vars. Black Wonder, Long Tom. S.A. Black and White and Tendergreen develop large local necrotic spots and veins in three days. There are also areas of almost yellow chlorosis on which the necrotic lesions are vividly marked. Fig. 2B. var. Idaho Refugee has only a local necrotic vein etching.

\section{Pisum sativum.} wilted.

Local. There are no lesions, but in 10 days the leaves have become necrotic and

Systemic. After a veinclearing and spotting of the young leaves, the next formed develop a mosaic. Necrosis sets in, in the chlorotic areas and in the veins, and the plant collapses. Secondary shoots have small, folded and mottled leaves, and the tendrils are abnormally curled.

\section{Trifolium hybridum.}

Local. There are chlorotic spots.

Systemic. After three weeks chlorotic spots develop on the young leaves while later ones have a chlorotic streak mottle.

\section{T. incarnatum.}

Local. A veinal necrosis results in a collapse of the leaves.

Systemic. In 18 days the veins of the young leaves become chlorotic then necrotic. Later ones are severely crinkled and puckered and have a mottle. The plant is extremely stunted and normally collapses.

\section{T. pratense.}

Local. No reaction.

Systemic. There are chlorotic streaks which become necrotic and cause a malformation of the leaf surface. 
T. repens.

Local. No reaction.

Systemic. There are chlorotic streaks but less necrosis and malformation than on $T$. pratense.

Vicia faba.

Local. In two weeks chlorotic spots with almost purple necrotic rings develop. The leaves wilt.

Systemic. A week later the young leaves show a veinclearing and chlorotic spotting. On later formed leaves these spots have necrotic haloes (Fig. 2A), and there is a necrosis of the growing point, which may collapse. Any secondary shoots which develop have leaves which are rolled and have a mosaic.

Vigna sesquipedalis.

Local. Chlorotic specks develop in two weeks. These fuse to a general chlorosis and the leaves wilt.

Systemic. The second trifoliates have chlorotic rings and a necrotic sheen. The young leaves are spotted and later mottled.

\section{V. unguiculata.}

Local. In two days there are necrotic specks and in six there are chlorotic areas.

Systemic. A week later the young leaves develop necrotic veins and they are curled down, and soon absciss. If more leaves form they are slightly malformed with irregular areas of chlorotic spots along the veins.

\section{Voandzeia subterranea.}

Local. No reaction.

Systemic. A dark green blistered mottle develops on most leaves.

\section{IDENTIFICATION}

There is a great resemblance between this virus and the white clover mosaic virus as described by Zaumeyeı and Wade (19).

Although the symptoms on all host plants are not identical, they are very similar. Also, the physical properties and host ranges of the two viruses are alike.

Therefore, this virus is considered the same as the white clover mosaic virus.

(No attempt has been made to isolate the two components, but the virus is described as it was found in the field.)

\section{SUMMARY}

In South Africa, three viruses occur naturally on Crotalaria juncea, viz. the alsike clover mosaic virus and strains of two bean viruses (described in the report on bean virus diseases).

On $C$. spectabilis there are four viruses which occur in the field-the white clover mosaic virus (as a complex), two bean viruses and one related to the broad bean mosaic virus (described under their respective headings).

Of these seven viruses, not one can be correlated with the Crotalaria viruses already reported in the literature.

The viruses of Bose and Misra (3) and Hadiwidjaja (10) both cause a witch's broom effect, which is not a feature of any of these viruses.

Gate's two diseases of $C$. spectabilis are not sap-transmissible (9), and the sunnhemp 
mosaic of Raychaudhuri (15) has only one host viz. sunnhemp. Although the viruses of Capoor (4) and Raychaudhuri and Pathanian (16) have much wider host ranges, their physical property values are very high e.g. Capoor's virus withstands heating up to $90^{\circ} \mathrm{C}$, and ageing to 557 days.

Too few details are available of the other Crotalaria diseases, for an accurate comparison to be made.

Schwartz (17), Cook (5), Illingworth (11), Fukushi (8) and Jenson (12) give only the symptoms on Crotalaria species. Dale (7) does include cowpea as a susceptible host, and Johnson and Lefebvre (14) describe only the reaction on broad bean.

It is therefore concluded that none of these Crotalaria viroses have been found during this survey in South Africa.

\section{Literature Cited}

1. (1949-50)................ Report of the Division of Mycology and Plant Pathology. Sci. Rept. Agric. Res. Inst. New Delhi. 1949-50, p. 81-88.

2. Anderson, C. W. (1955)....... Vigna and Crotalaria viruses in Florida. Pl. Dis. Reptr., 39: $346-357$.

3. Bose, R. D. and Misra, S. D. Studies in Indian fibre plants No. 6. Phyllody and some (1938) other abnormalities in the flower of sunnhemp. Ind. Jour. Agric. Sci., 8: 417-423.

4. Capoor, S. P. (1950).......... A mosaic disease of sunnhemp in Bombay. Curr. Sci., 19: 22.

5. Соок, М. T. (1931)......... New virus diseases in Puerto Rico. Phytopathology (Abstract), 21: 124.

6. Соок, М. T. (1931).......... The effect of mosaic on cell structure and chloroplasts. Jour. Dept. Agric. Puerto Rico, 15: 177-181.

7. Dale, W. T. (1943)............ Preliminary studies of the plant viruses in Trinidad. Trop. Agric., 20: 228-235.

8. FukUshi, T. (1932).

A contribution to our knowledge of virus diseases of plants in Japan. Trans. Sapporo Nat. Hist. Soc., 7: 130-141. (Abstr. Rev. Appl. Myc., 11: 797).

9. Gates, C. M. (1950)

A mosaic and little leaf disease of Crotalaria spectabilis in South Florida. PI. Dis. Reptr., 34: 203-204.

10. Hadiwidjaja, T. (1952)........ Die krul- of heksenbezemziekte van Crotalaria. Tijdschr. over Plantenz., 58: 1-4.

11. Illingworth, J. F. (1931)....... Yellow spot of pineapples in Hawaii. Phytopathology, 21: $865-880$.

12. Jenson, D. D. (1950).......... A Crotalaria mosaic and its transmission by aphids. Phytopathology, 40: 512-515.

13. Johnson, F. (1942)........... The complex nature of white clover mosaic. Phytopathology 32: $103-116$.

14. Johnson, H. W. And Lefebvre, Crotalaria mosaic. Phytopathology (Abstr.) 28: 10. C. L. (1938)

15. Raychaudhuri, S. P. (1947).....

16. Raychaudhuri, S. P. and PathaNIAN, P. S. (1950)

A note on mosaic virus of sunnhemp (Crotalaria juncea Linn.) and its crystallisation. Curr. Sci., 16: 26-28.

17. SChWARTZ, M. B. (1927)........

mosaic disease of Crotalaria mucronata Desv. (C. striata D.C.). Curr. Sci., 19: 213.

Eenige ziekten van onbekenden aard bij groenbemesters. Korte Meded. Inst. voor Plantenziekten, 5: 1-19.

18. ZAUMeYeR, W. J. (1940)........ Three previously undescribed mosaic diseases of pea. Jour. Agric. Res., 60: 433-452.

19. Z Z AumeYer, W. J. AND WADE, B. L. The relationship of certain legume mosaics to bzan. Jour. (1935) Agric. Res., 51: 715-747. 


\section{SOYBEAN VIRUS DISEASES}

In the field, soybean (Glycine max) is apparently susceptible to three viruses-one of which is the seed-borne soybean mosaic virus.

This soybean mosaic virus has been found in the Northern, Eastern and Western Transvaal-but probably occurs wherever soybeans are cultivated, as the percentage of infected seed can be high.

The other two viruses found on naturally infected soybeans are described in detail in the report on bean virus diseases; as they were proved to be strains of the bean chlorotic ringspot and bean local chlorosis viruses.

The field symptoms of the latter two viruses include mottling, puckering and malformation of the leaves, and stunting of the plants.

\section{REVIEW OF LITERATURE}

Clinton 1916, was the first to report a chlorosis and crinkling of soybean leaves. The virus origin of this chlorosis was established by Gardner and Kendrick in 1921 . Pierce (11) named the causal organism soybean virus 1, and in Kenneth Smith's classification it is Soja virus 1.

The virus can be transmitted in the seed of infected plants where it can survive for two years, Kendrick and Gardner (8). It is also aphis transmitted.

Heinze and Köhler (6) and Conover (3) were able to infect Phaseolus vulgaris and Vicia sativa, but these hosts have not been confirmed by other workers.

Savulescu et al (12) described three types of symptom on soybeans-leaf curl, brown mosaic and yellow mosaic. These variants have a thermal inactivation point of $80^{\circ} \mathrm{C}$., which is much higher than is generally accepted for the soybean mosaic virus.

According to Ling (10) the only legume viruses found on naturally infected soybeans are the bean yellow mosaic virus and the cowpea mosaic virus of Dale.

However, many other legume viruses can induce symptoms on soybeans when inoculated artificially.

The top necrosis, streak and budblight diseases of soybean are now attributed to strains of the tobacco ringspot virus. Allington (1) and Johnson (7). This virus is also seed-transmitted in soybeans. Desjardins et al (4).

The tomato spotted wilt virus results in local necrotic specks surrounded by chlorotic haloes. The rest of the leaf may be almost orange in colour. There is no systemic reaction. (See report on pea virus diseases.)

\section{SOYBEAN MOSAIC VIRUS Gardner and Kendrick.}

Transmission: Mechanical sap inoculation. By seed. (One land had approximately $35 \%$.) Aphis. (Species not determined.)

Hosı range: Glycine max (L.) Merr.

Symptoms on Glycine max:

(a) Artificial infection in the glasshouse:

Local. No reaction.

Systemic. The young leaves develop chlorotic spots in three weeks. This is followed by a mottle and slight malformation on the next formed leaves. Often, necrotic rings develop round the chlorotic spots as the leaves mature.

The plant is stunted, and has a proliferation of secondary shoots which remain rosetted. 
(b) Natural infection in the field:

In a land of maturing soybeans, infected plants are noticeable for their lush green foliage, when other plants have dropped most of their leaves.

These plants are stunted, and have a great number of lateral branches.

The leaves are mottled, crinkled and slightly malformed. They later become leathery.

(c) Seed infection in the glasshouse:

The primary leaves are mottled and crinkled with wavy margins. The trifoliates have the usual symptoms.

The plants are spindly and etiolated.

\section{IDENTIFICATION}

As this virus is seed-borne, and has only one host plant viz. the soybean, there can be little doubt that it is the soybean mosaic virus.

\section{Literature Cited}

1. Allington, W. B. (1946)...... Budblight of soybean caused by the tobacco ringspot virus. Phytopathology (Note), 36: 319.

2. Cuinton, G. P. (1916)......... Report of the botanist for 1915. Conn. Agric. Exp. Sta. Ann. Rept., 1915. p. 446.

3. Conover, R. A. (1948)

Studies of two viruses causing mosaic diseases of soybean. Phytopathology, 38: 724-735.

4. Desjardins, P. R., Latterell, Seed transmission of tobacco-ringspot virus in Lincoln R. L. AND MitchelL, J. E. (1954) variety of soybean. Phytopathology (Note) 44: 86.

5. Gardner, M. W. And Kendrick, Soybean mosaic. Jour. Agric. Res., 22: 111-114. J. B. (1921)

6. Heinze, K. And Köhler, E. (1940)

Die Mosaikkrankheit der Sojabohne und ihre Ubertragung durch Insekten. Phytopath. Zeitschr., 13: 207-242.

7. Johnson, F. (1943)........... Soybean streak in Ohio. Pl. Dis. Reptr., 27: 86-87.

8. Kendrick, J. B. ANd Gardner, Soybean mosaic: seed transmission and effect on yield. M. W. (1924) Jour. Agric. Res., 27: 91-98.

9. Kreitlow, K. W., Boyd, H. C., Chamberlain, D. W. and DunLEAVY, J. M. (1957)

10. LING, L. (1951)

A bibliography of viruses infecting the soybean [Glycine $\max$ (L.) Merr.]. Pl. Dis. Reptr., 41: 579-588.

Bibliography of soybean diseases. PI. Dis. Reptr. Suppl., 204: 111-173.

11. Pierce, W. H. (1935)......... The identification of certain viruses affecting leguminous plants. Jour. Agric. Res., 51: 1017-1039.

12. Sảvulescu, T., Sandu-Ville, C., L’état phytosanitaire en Roumanie en 1934-1935. Publ. ARONescu, A. AND Alexandri, Inst. Cerc. Agron. României, 25: 1-97. (Abstr. Rev. A. V. (1936) App. Myc., 16: 19.) 


\section{LUCERNE (ALFALFA) MOSAIC VIRUSES}

The typical lucerne mosaic virus occurs naturally on lucerne in many districts of the Union.

One variant of this virus was found in the Western Cape, also on lucerne; and another was isolated from Glycine javanica growing in experimental plots in Pretoria. These three viruses will be described below.

The necrotic ring strain of lucerne mosaic virus, which was commonly found on raturally infected peas and sweet peas, has been described in the report on the virus diseases of peas and sweet peas.

The word "lucerne" is used in preference to "alfalfa", as it is the common name for Medicago sativa in this country.

Natural source of virus:

(a) Lucerne mosaic virus-type. (TYPE*) Medicago sativa. Some leaves had a chlorotic network, spotting or streaking, while others had dark green blisters and were severely puckered.

(b) Lucerne mosaic virus-necrotic strain. (NECR. STr.) M. sativa. The leaves were diffusely mottled and slightly malformed.

(c) Lucerne mosaic virus-Glycine strain. (Glyc. STR.) Glycine javanica. Most leaves had irregular, vivid yellow markings. There was no malformation. See Fig. 5A.

Physical properties:

Thermal inactivation point (all 3) $62-64^{\circ} \mathrm{C}$.

Longevity in vitro. TYPE AND NECR. STR. 2-4 days.

Glyc. Str. 6-8 days.

Dilution end point (all 3) 1:3000-1:5000.

Transmission:

All three are mechanically sap transmissible.

TYPE AND NECR. STR. Aphis craccivora.

Aphis fabae.

Glyc. STR. Results inconclusive.

HOST RANGes.

\begin{tabular}{|c|c|c|c|}
\hline & TYPE & NECR. STR. & GLYC. STR. \\
\hline 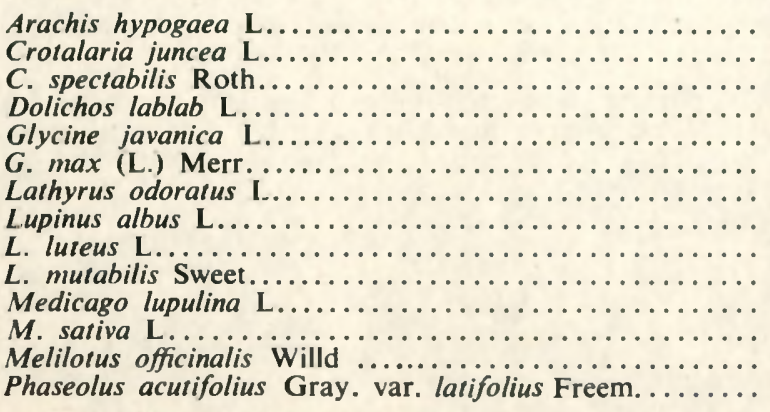 & $\begin{array}{l}+ \\
+ \\
+ \\
+ \\
+ \\
+ \\
+ \\
+ \\
+ \\
+ \\
+\end{array}$ & $\begin{array}{l}+ \\
+ \\
- \\
+ \\
+ \\
+\end{array}$ & $\begin{array}{l}+ \\
+ \\
+ \\
+ \\
+ \\
+ \\
+ \\
+ \\
+ \\
+ \\
+ \\
+ \\
+\end{array}$ \\
\hline
\end{tabular}

*Abbreviations to be used in the text. 


\begin{tabular}{|c|c|c|c|}
\hline & TYPE & NECR.STR. & GLYC. STR. \\
\hline 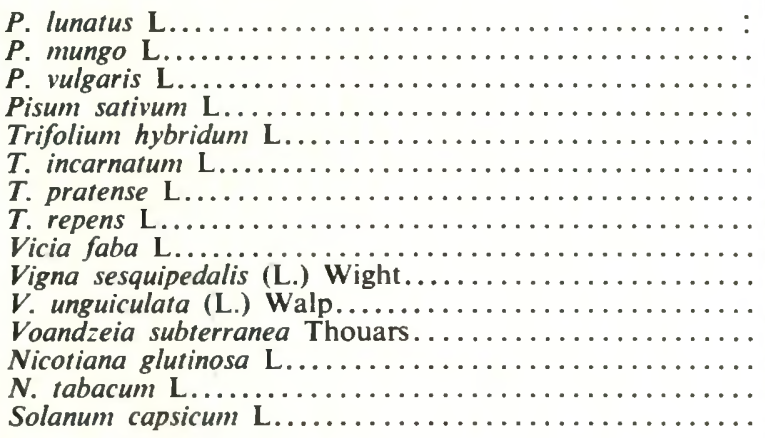 & $\begin{array}{l}+ \\
+ \\
+ \\
+ \\
+ \\
+ \\
+ \\
+ \\
+ \\
+ \\
+\end{array}$ & $\begin{array}{l}+ \\
+ \\
+ \\
+ \\
+ \\
+ \\
+ \\
+ \\
+ \\
+ \\
+ \\
+\end{array}$ & $\begin{array}{l}+ \\
+ \\
+ \\
+ \\
+ \\
+- \\
+ \\
+ \\
- \\
+ \\
+ \\
+ \\
+ \\
- \\
-\end{array}$ \\
\hline
\end{tabular}

\section{REACTION OF SUSCEPTIBLE SPECIES}

Arachis hypogaea.

Local. No reaction.

Systemic. TYPE. A dark green mottle develops.

NECR. STR. There is an irregular chlorotic streak mottle and occasional patterns.

Glyc. Str. Not tested.

Crotalaria juncea.

Local. Necrotic specks develop with all three. Fig. 4B.

Systemic. TYPE. The growing point curves to one side and the young leaves have a chlorotic network. Later formed leaves develop dark green blisters, and are malformed or even stringlike.

NeCR. STR. Most leaves are mottled and elongated, with wavy margins. Later, necrotic specks develop.

Glyc. STR. The leaves show a chlorotic network and then a mottle. The chlorotic areas extend across the leaf. thereby constricting the lamina.

Crotalaria spectabilis. Only the GLyc. STR. was tested.

Local. No reaction.

Systemic. A chlorotic speckling develops.

Dolichos lablab.

Local. TyPE. Small necrotic specks develop.

Glyc. Str. There is a veinal necrosis and collapse.

Systemic. TYPE. Some leaves develop a chlorotic spotting.

Glyc. STR. A vein clearing of the young leaves, is followed by yellow vein flecks on later formed leaves. The plant is stunted.

Glycine javanica.

Local. Glyc. Str. Small necrotic specks and veins develop in two days. 
Systemic. Glyc. STr. In three weeks the young leaves show a vein-clearing. Later formed leaves have irregular yellow areas or concentric patterns.

The symptoms in the glasshouse are not as vivid as those in the field.

Glycine max.

Local. TYPE. No reaction.

GLYC. STR. There are necrotic specks, rings and veins.

Systemic. TYPE. There are chlorotic spots and later a mottle.

GLYC. STR. In three weeks the young leaves develop a chlorotic network or star flecks. Later formed leaves have vivid yellow areas, Fig. $4 \mathrm{~F}$ and the plant is stunted.

Lathyrus odoratus. Only the Glyc. STR. was tested.

Local. No reaction.

Systemic. A chlorotic mottle develops.

Lupinus albus.

Local. TyPE. Necrotic specks develop in 5-6 days.

NeCR. AND Glyc. STR. There are necrotic specks with chlorotic haloes. The necrosis spreads and the leaves absciss. Fig. 4G.

Systemic. TYPE AND NECR. STR. The leaves remain folded, and they have wavy margins. There is a mottle, and fine necrotic speckling on most leaves. The plant is rosetted.

Glyc. Str. As above, but no necrosis. In addition, the leaves are malformed and almost stringlike and there are dark green blisters.

L. luteus.

Local. TyPE AND Necr. STR. The leaves collapse after necrosis.

Glyc. STR. No reaction.

Systemic. TYPE. The leaves have broad dark green veinbands, and the tips are twisted.

NECR. STr. The leaves are mottled and have necrotic specks. They remain small and the plant is rosetted.

Glyc. STR. The young leaves develop chlorotic spots. Later formed ones have irregular dark green areas or blisters. They are also malformed or stringlike, and the plant is stunted.

L. mutabilis. Only the Glyc. Str. was tested.

Local. No reaction.

Systemic. The leaves are chlorotic with dark green marginal blisters. They are severely rolled.

Medicago lupulina.

Local. No reaction with the TyPE AND Glyc. STR.

Systemic. TYPE. Most leaves are mottled and puckered.

GLYC. STR. There is a diffuse chlorotic streaking.

M. sativa.

Local. TYPE. Necrotic specks develop in 5-6 days.

NeCR. AND Glyc. Str. No reaction.

Systemic. TYPE. The young leaves develop chlorotic spots and later ones are mottled and slightly crinkled.

NECR. Str. The young leaves have chlorotic, almost white spots, which may become necrotic. On later formed leaves there are irregular yellow areas which cause a malformation. The old leaves have chlorotic blotches. 
Glyc. Str. Only a diffuse mottle develops.

Melilotus officinalis.

Local. Glyc. Str. Chlorotic blotches develop.

Systemic. Glyc. Str. The young leaves have chlorotic spots or streaks along the veins, which cause a distortion. Later leaves are small, crinkled and rolled, with irregular chlorotic areas. The plant is stunted.

This plant is a symptomless carrier for the TYPE virus.

Phaseolus acutifolius.

Local. TYPE. There are chlorotic spots and rings.

NeCR. Str. There are many necrotic lesions which fuse to give a "scorch" effect.

Glyc. Str. No reaction.

Systemic. With all three, there is a veinclearing followed by a mottle. With the TYPE virus there are also dark green veinbands.

\section{P. lunatus.}

Local. TyPE. Chlorotic spots develop in 4-5 days.

Glyc. Str. There are large chlorotic blotches. leaves.

Systemic. Only with the GLYC. STR. are there chlorotic vein flecks on the older

\section{P. mungo.}

Local. TYPE. No reaction.

Glyc. Str. The veins become necrotic.

Systemic. TYPE. The young leaves develop chlorotic spots with necrotic centres. Glyc. Str. There are vivid yellow vein flecks.

P. vulgaris var. Canadian Wonder.

Local. TYPE. There are necrotic rings with almost white centres. Fig. 3A.

Necr. Str. The lesions are similar, but they have irregular outlines. Fig. 3B.

Glyc. Str. There are necrotic lesions and considerable veinal necrosis. Fig. 3C.

Systemic. TyPe And Glyc. Str. No reaction.

NeCr. Str. Isolated necrotic lesions develop along the veins of the trifoliate leaves. (These lesions are of the same type as occur on the inoculated leaves.) They result in the uneven growth of the var. Haricot. laminae. Fig. 3D.

Local. The necrotic lesions are similar to those on Canadian Wonder: but large areas of these leaves become chlorotic, and the leaves drop.

Systemic. NECR. STR. There is often a severe veinal necrosis which results in the collapse of the plant.

\section{Pisum sativum.}

Local. Type and Glyc. Str. No reaction.

NeCR. Str. There are necrotic lesions in 5-6 days.

Systemic. TYPE. After a vein clearing of the young leaves the next ones develop chlorotic spots. Older leaves have, a chlorotic vein etching.

NeCR. Str. No reaction.

GLYC. StR. The leaves are mottled and malformed, and they remain folded. The tendrils are abnormally curled. 
Trifolium hybridum.

Local. Glyc. Str. No reaction.

Systemic. Glyc. Str. There are chlorotic streaks and rings, and on later formed leaves, a general chlorosis. As the leaves mature. necrosis sets in, in the chlorosis.

This plant is a symptomless carrier of the TYPE virus.

T. incarnatum.

Local. TYPE. The leaves become chlorotic leaving dark green rings with central necrotic specks.

NeCr. AND Glyc. Str. No reaction.

Systemic. With all three there is a chlorotic network followed by a mosaic, and the leaves are crinkled.

TYPE. In addition, the plants are severely stunted and rosetted. Fig. 4E.

GLYC. STR. There are well-defined dark green veinbands on most leaves. Fig. 4D.

T. pratense.

Local. TyPe AND Glyc. Str. Necrotic specks develop in 5-6 days.

Systemic. TYPE. Some plants have a chlorotic mottle, but with others, the virus is latent.

Glyc. Str. The virus is latent but can be recovered.

T. repens.

Local. TYPE. No reaction.

Systemic. TYPE. Chlorotic streaks develop.

This plant is a symptomless carrier for both the NECR. and Glyc. strains.

Vicia faba.

Local. With all three there are red necrotic lesions which may fuse with closely adjacent ones. Fig. 4A.

The leaves become
Systemic. TYPE. No reaction.

NECR. StR. After an initial vein-clearing there may be a lethal necrosis.

GLYC. StR. A diffuse chlorotic mottle develops.

Vigna sesquipedalis.

Local. TYPE. Chlorotic spots develop.

NeCR. AND GlyC. Str. There are necrotic specks.

Systemic. TyPE AND NeCR. STr. After a vein clearing there is a chlorotic speck mottle.

Glyc. Str. No reaction.

V. unguiculata.

Local. TYPE. There are small necrotic lesions. Fig. 4C.

NECR. AND GLYC. STR. In addition, the rest of the leaves become chlorotic, and they soon drop.

Systemic. TyPe and Glyc. Str. There is a diffuse mottle.

NECR. STR. Chlorotic spots and necrotic specks develop on the young leaves. On the older ones there are necrotic rings, and the leaves absciss.

\section{Voandzeia subterranea.}

Local. Necr. ANd Glyc. Str. No reaction. 
Systemic. NeCR. STR. There are chlorotic spots and later a mottle.

GLYc. STR. The leaves are small and puckered, and they are mottled with dark green veinbands and blisters.

Nicotiana glutinosa.

Local. TyPe AND NeCR. STR. There are small necrotic rings with almost white centres. Fig. 5B.

Systemic. TyPE AND NeCR. Str. A chlorotic spot mottle develops.

N. tabacum.

Local. TYPE. Chlorotic spots develop in six days.

NECR. STr. There are irregular almost white lesions.

Systemic. TYPE. No reaction.

NeCR. Str. There is a diffuse chlorotic spotting.

Solanum capsicum.

Local. TYPE. There are chlorotic spots in six days.

NeCR. Str. Necrotic lesions develop.

Systemic. TYPE. The leaves are mottled and malformed or cupped.

NECR. STR. There are necrotic rings or irregular patterns which result in a malformation of the leaf.

\section{IDENTIFICATION.}

(a) TYPE.- On the basis of host range (including families other than Leguminosae), symptoms and physical properties, this virus is classified as lucerne (alfalfa) mosaic virus. Weimer $(22,23)$.

(b) Necrotic Strain.-This virus results in both local and systemic necrosis on bean, and it is therefore firstly compared with others causing a similar symptom.

(i) On some varieties of bean, both the bean Southern mosaic virus, Zaumeyer and Harter (26) and the bean pod mottle virus, Zaumeyer and Thomas (27) cause a local and systemic necrosis. However, both have very restricted host ranges, and the physical properties values differ considerably from those for this virus. Further the pod mottle virus causes a far more severe necrosis on bean.

(ii) The pea New Zealand streak virus, Chamberlain (3) differs in the type of necrosis on bean, pea and lupin, and causes only local lesions on the Trifolium species. The physical properties also differ.

(iii) There are several other viruses and strains of lucerne mosaic virus which result in both local and systemic necrosis on bean, but the differences in the type of necrosis and symptoms on other hosts are too great for closer comparisons to be made.

(iv) There is apparently a relationship with the lucerne (alfalfa) mosaic virus group, as the symptoms on many hosts and the physical properties are very similar.

However, this virus cannot be wholly identified with any previously described strain. and it is therefore named lucerne mosaic virus, NECROTIC strain.

(c) Glycine Strain.-There are many similarities between this virus and those in the lucerne mosaic virus group, in respect of symptom expression on several hosts and physical property values.

However, it differs from them in being non-infectious to the solanaceous plants, and the reaction of broad bean, soybean and pea etc. is different. Moreover, many species show a vivid yellow mottle instead of the usual chlorosis. Relationship with the lucerne mosaic virus is probable and it is named the GLYCINE strain. 


\section{Literature Cited}

1. Berkeley, G. H. (1947)........

2. Black, L. M. and Price, W. C (1940)

3. Chamberlain, E. E. (1939)......

4. Houston, B. R. and Oswald, J. W. (1953)

5. JOHNSON, E. M. (1946)

6. Kovačevski, I. C. (1942).......

7. Kreitlow, K. W. and Price, W. C. (1949)

8. MCWhorter, F. P. (1949).......

9. Milbrath, J. A. (1952).........

10. Milbrath, J. A. ANd McWhorter, F. P. (1954)

11. Oswald, J. W. (1950)

12. Pierce, W. H. (1934)..........

13. (1935)...............

14. Porter, D. R. (1931)

15.

(1935)

16. Price, W.

C. (1940)

17. Ross, A. F. (1941)

18. Ммітн, K. М. (1957)

19. SNYder, W. C. AND Rich, S. (1942)

20. Thomas, H. R. (1951).

21. (1953)

22. Weimer, J. L. (1931).

23.

25. (1953)

26. AND HARTER, L. L. (1943)

27. (1948) AND THOMAS, $\mathrm{H} . \mathbf{R}$
A strain of alfalfa mosaic virus on pepper in Ontario. Phytopathology, 37: 781-789.

The relationship between viruses of potato calico and alfalfa mosaic. Phytopathology, 30: 444 447.

Pea streak (Pisum virus 3). N.Z. Jour. Sci. Tech., 20: 365A$381 \mathrm{~A}$.

The mosaic virus disease complex of ladino clover. Phytopathology, 43: 271-276.

Two legume viruses transmissible to tobacco. Phytopathology, 36: 142-147.

Die Buntblättrigkeit der Paprikapflanze (Capsicum annuum) (Medicago virus $2 \mathrm{~K}$. Smith var. typicum Black u. Price). Zeitschr. Pflanzenkr. 52: 533-540.

A new virus disease of ladino clover. Phytopathology, 39: 517-528.

Alfalfa virus N. Phytopathology (Abstr.) 39: 861.

Variations in potato calico caused by strains of alfalfa mosaic. Phytopathology (Abstr.) 42: 516-517.

Response of cowpea varieties to strains of alfalfa mosaic. virus. Phytopathology (Abstr.) 44: 498.

A strain of alfalfa-mosaic virus causing vine and tuber necrosis in potato. Phytopathology, 40: 973-991.

Viroses of the bean. Phytopathology, 24: 87-115.

The identification of certain viruses affecting leguminous plants. Jour. Agric. Res., 51: 1017-1039.

The infectious nature of potato calico. Hilgardia, 6: 277-294.

Insect transmission, host range and field spread of potato calico. Hilgardia, 9: 383-394.

Comparative host ranges of six plant viruses. Amer. Jour. Bot., 27: 530-541.

Purification and properties of alfalfa-mosaic virus protein. Phytopathology, 31: 394-410 and 410-420.

A textbook of plant virus diseases. Published by Churchill, L.td., London.

Mosaic of celery caused by the virus of alfalfa mosaic. Phytopathology, 32: 537-539.

Yellow dot, a virus disease of bean. Phytopathology, 41: 967-974.

Isolation of alfalfa mosaic virus strains from field-grown beans. Pl. Dis. Reptr., 37: 391-392.

Alfalfa mosaic. Phytopathology, 21: 122-123.

Studies on alfalfa mosaic. Phytopathology, 24: 239-247.

A streak disease of peas and its relation to several strains of alfalfa mosaic virus. Jour. Agric. Res., 56: 747-772.

Alfalfa yellow mosaic virus systemically infectious to beans. Phytopathology, 43: $38-42$.

Two new virus diseases of beans. Jour. Agric. Res., 67: 305-327.

Pod mottle, a virus disease of beans. Jour. Agric. Res., 77: $81-96$.

28. AND WADE, B. L. (1935)
The relationship of certain legume mosaics to bean. Jour Agric. Res., 51: 715-749. 


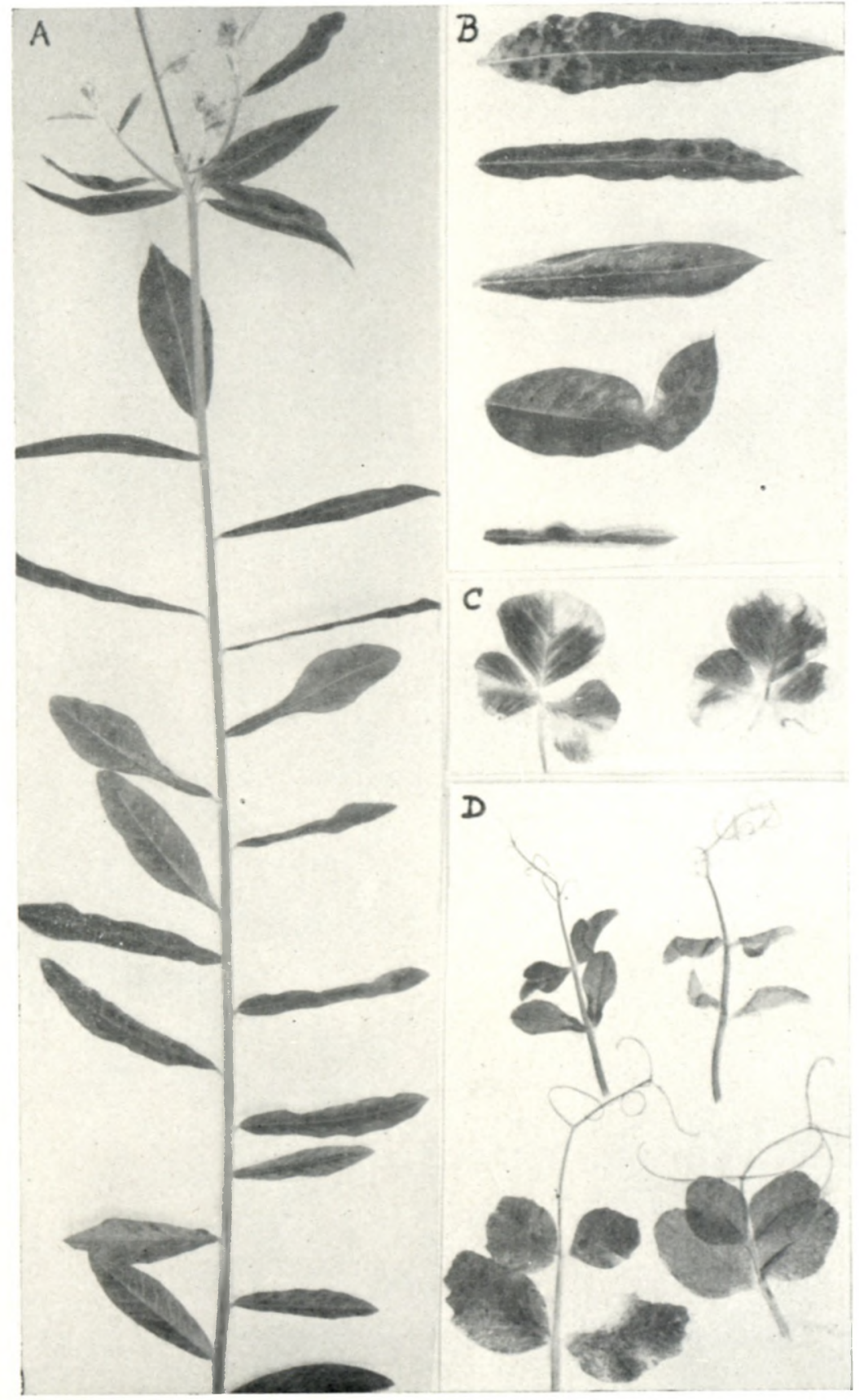

Fig. 1.-Alsike Clover Mosaic Virus 1.

A. Crotalaria juncea-natural infection. B. C. juncea-artificial infection. C. Medicago lupulina. D. Pisum sativum. 

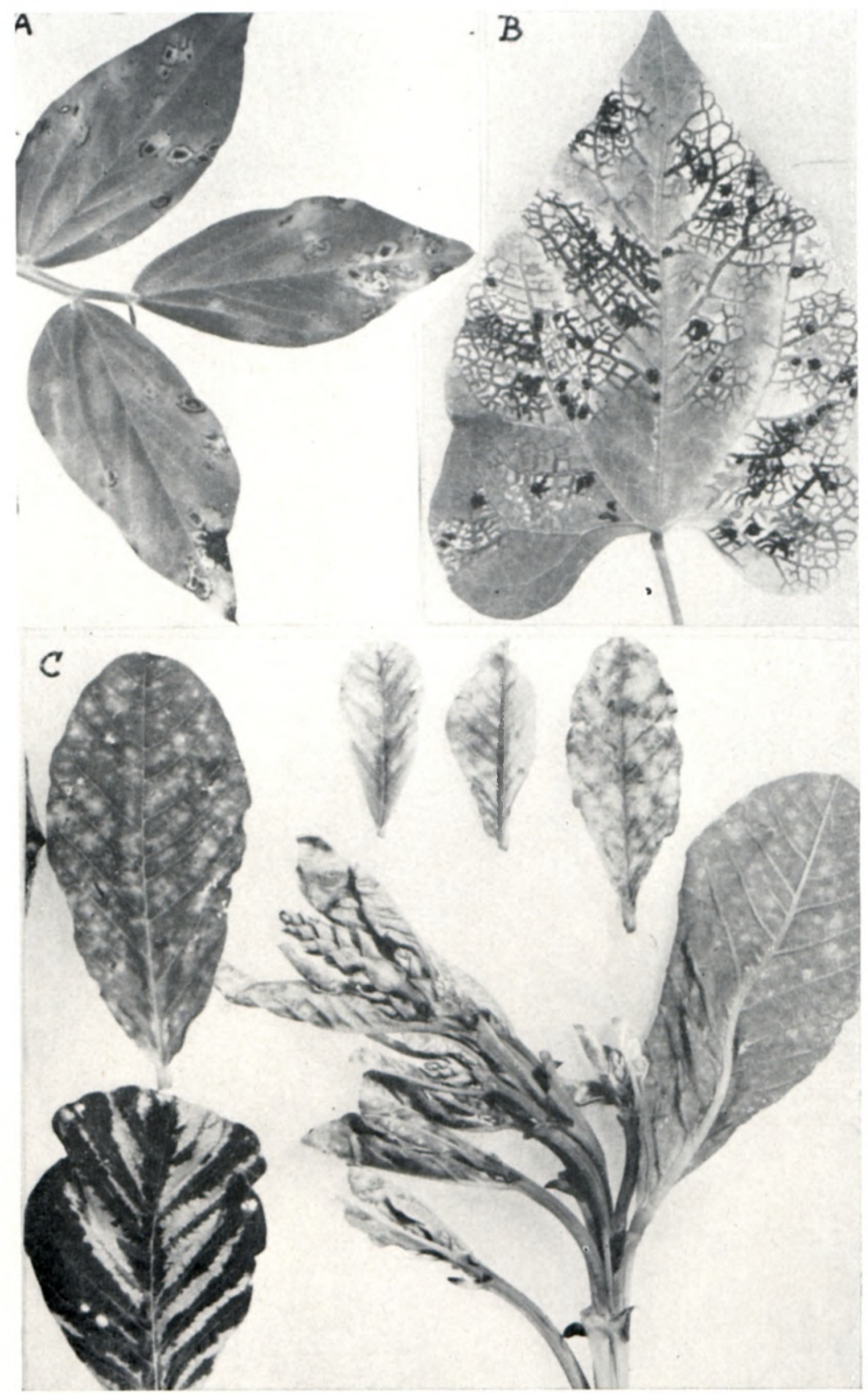

Fig. 2.-White Clover Mosaic Virus.

A Vicia faba. B. Phaseolus vulgaris. C. Crotalaria spectabilis. 

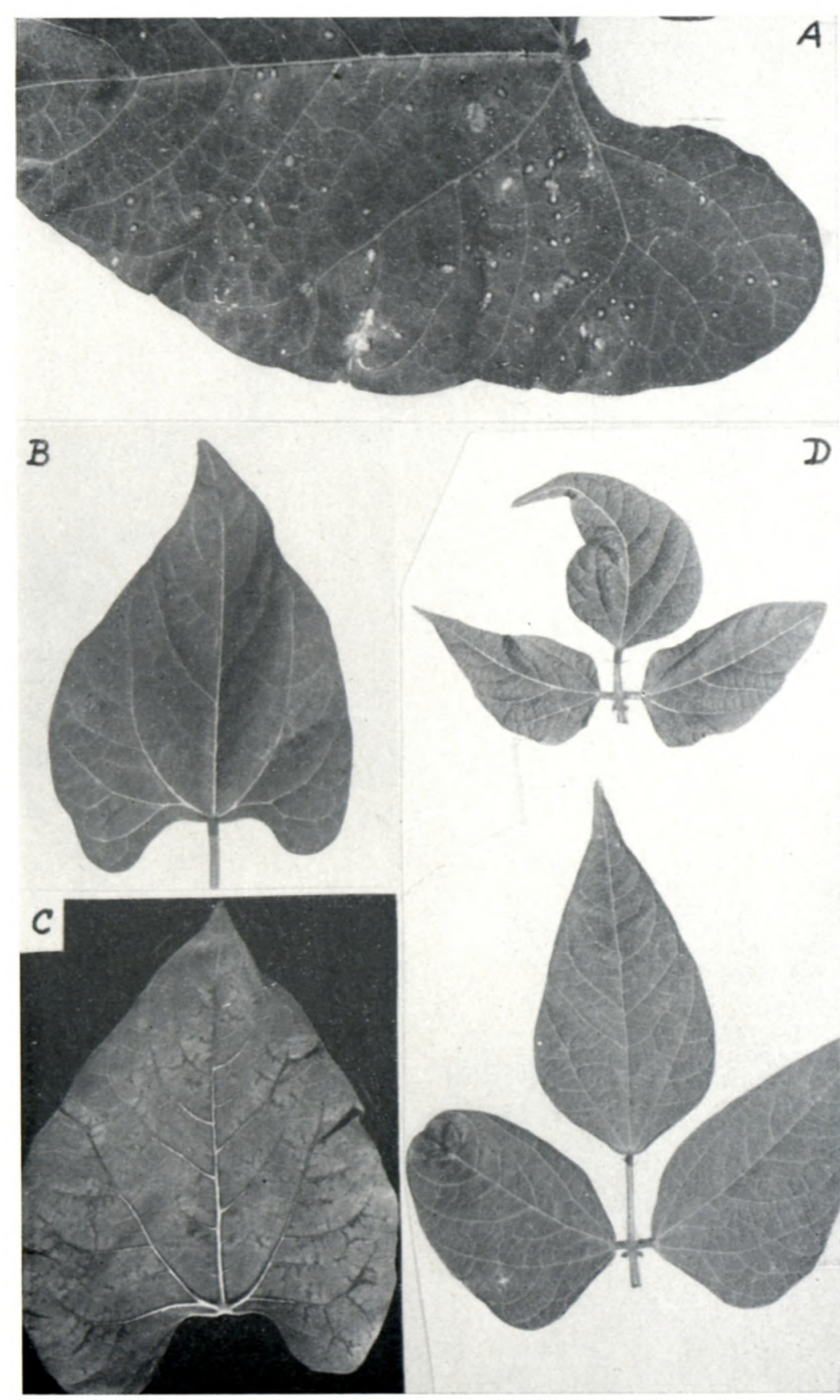

D

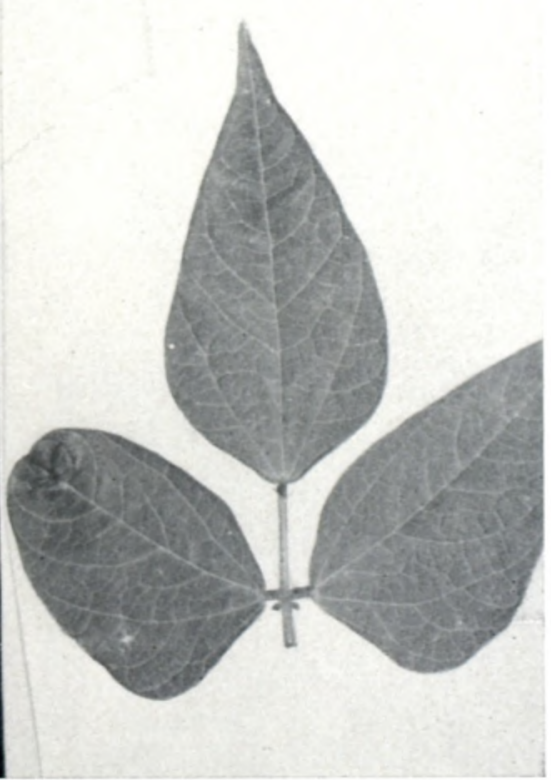

Fig. 3.-Lucerne Mosaic Virus Strains.

A-D. Phaseolus vulgaris-local lesions with A. TyPE virus. B. NeCrotic strain. C. Glycine strain. D. Systemic lesions with the NECROTIC strain. 

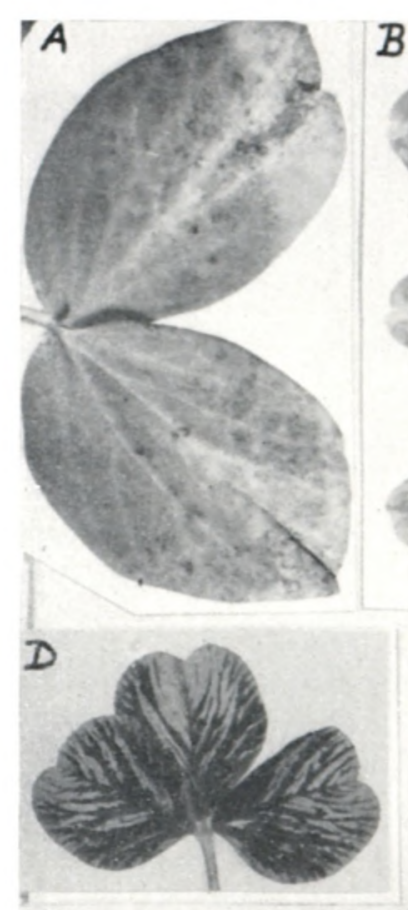

E

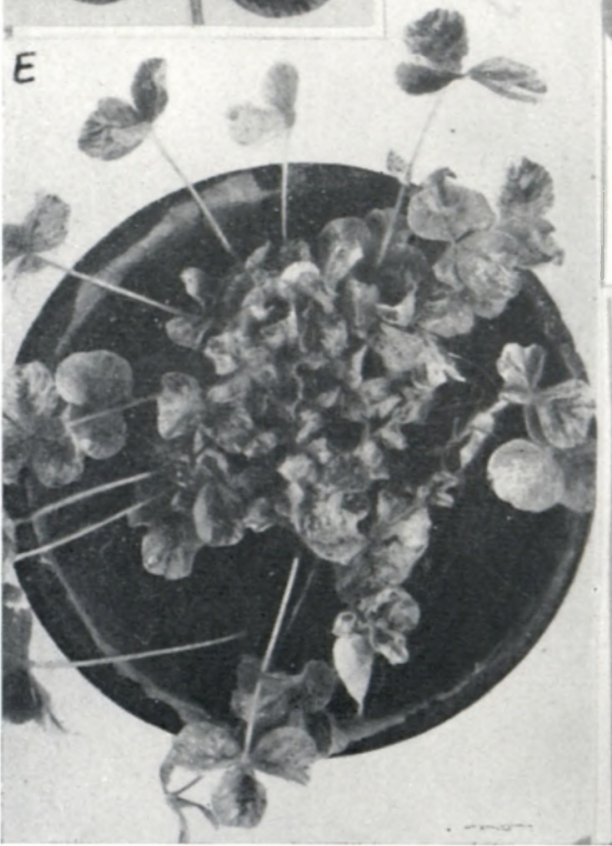

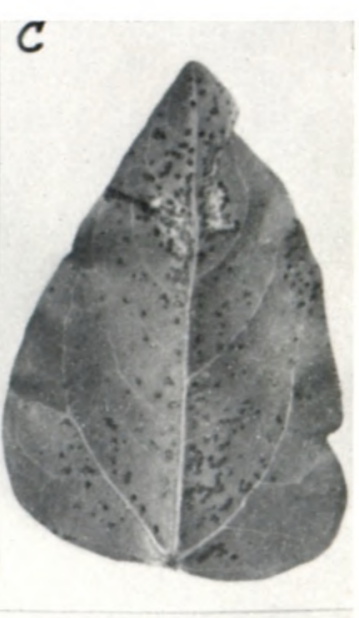

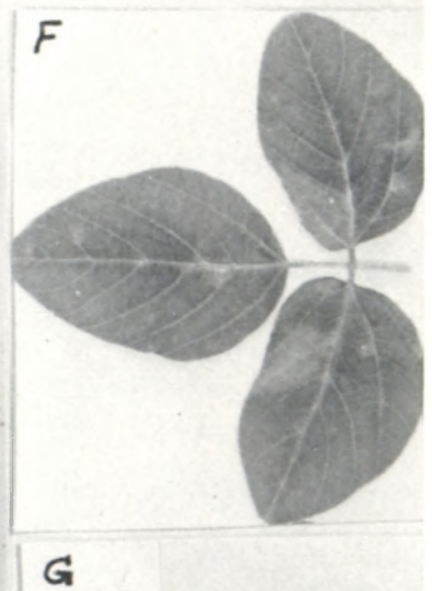

G

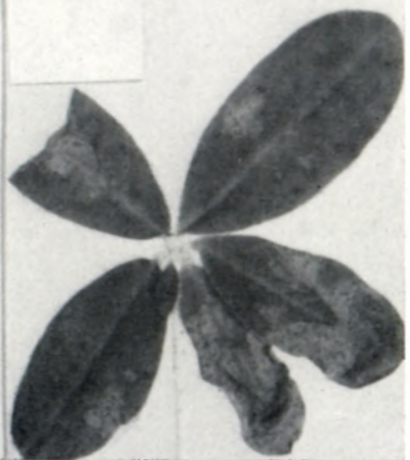

Fig. 4.-Lucerne Mosaic Virus Strains.

A. Vicia faba. B. Crotalaria juncea. C. Vigna unguiculata with the TYPE virus. D-E. Trifolium incarnatum. D. GLYCINE strain. E. TYPE virus. F. Glycine max with the GLYCINE strain. G. Lupinus albus with the NECROTIC or GLYCINE strains. 


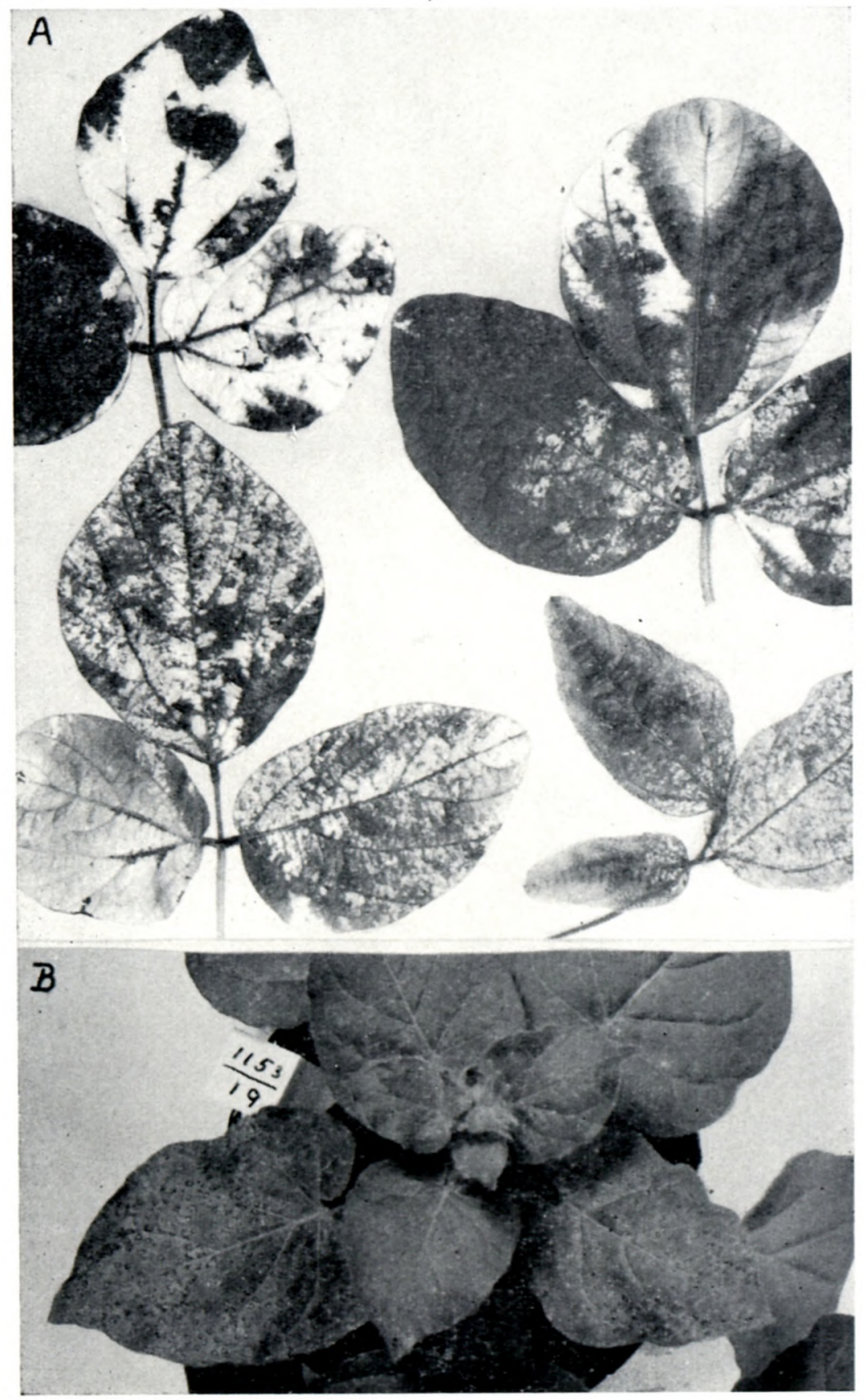

Fig. 5.-Lucerne Mosaic Virus Strains.

A. Glycine javanica-natural infection. B. Nicotiana glutinosa-local lesions. 
